\title{
Menengok Kembali Budaya Dan Masyarakat Megalitik Bondowoso
}

\section{Muhammad Hidayat}

Keywords: distribution, megalithic, culture, east java, typology, character

\section{How to Cite:}

Hidayat, M. (2007). Menengok Kembali Budaya Dan Masyarakat Megalitik Bondowoso. Berkala Arkeologi, 27(1), 19-30. https://doi.org/10.30883/jba.v27i1.940

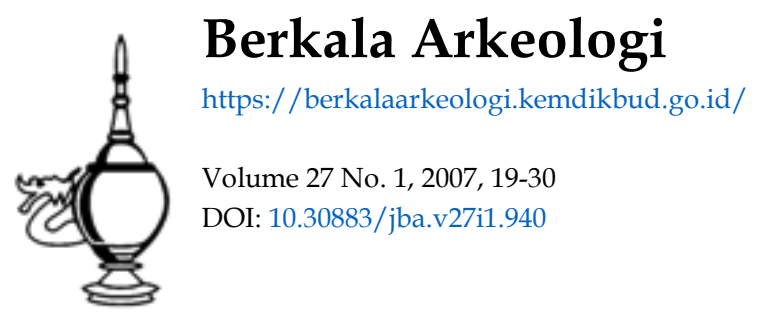

\section{(c) (1)(2)}

This work is licensed under a Creative Commons Attribution-NonCommercial-ShareAlike 4.0 International License. 


\title{
MENENGOK KEMBALI \\ BUDAYA DAN MASYARAKAT MEGALITIK BONDOWOSO
}

\author{
Muhammad Hidayat \\ (Balai Arkeologi Yogyakarta)
}

I. Budaya Megalitik Bondowoso: Permasalahan, Jenis, dan
Persebarannya Tinggalan budaya megalitik di wilayah Jawa Timur bagian timur seperti di wilayah Jember, Bondowoso, Situbondo, dan Banyuwangi cukup banyak. Dari beberapa penelitian selama ini diketahui bahwa peninggalan yang terdapat di wilayah Bondowoso sangat padat sebarannya, dan variasi hasil budayanya paling banyak. Oleh karenanya tidaklah salah jika ada yang menyebut bahwa di daerah timur Jawa Timur tersebut merupakan kerajaan megalitik dengan ibukotanya di Bondowoso. Khususnya terhadap peninggalan megalitik di Bondowoso ini sudah sering dilakukan penelitian. Namun penelitian-penelitian yang telah dilakukan tidak dapat menjawab secara tuntas terhadap permasalahan mengenai peninggalan tersebut. Permasalahan-permasalahan akademik baru terus bermunculan dan menuntut informasi-informasi/data baru untuk menjawabnya. Demikian pula munculnya/ditemukannya data baru yang menuntut penjelasan. Diantara permasalahan yang hingga kini belum terjawab secara memuaskan adalah mengenai masyarakat pendukung budaya megalitik dan masa perkembangannya.

Dari beberapa penelitian-penelitian yang telah dilakukan, dan yang terakhir dilakukan oleh Balai Arkeologi Yogyakarta melalui survei pada tahun 2004 diketahui bahwa di wilayah Bondowoso terdapat berbagai peninggalan budaya megalitik diantaranya adalah Sarkofagus (pandhusa), Dolmen, Kubur Kamar Batu, Teras Berundak, Menhir, arca, maupun Batu Kenong. Pada masanya, tinggalan-tinggalan ini berfungsi sebagai sarana penguburan maupun pemujaan. Sebagai sarana penguburan, yaitu sebagai wadah kubur berupa Sarkofagus, Dolmen, dan Kubur Kamar Batu, sedang sebagai sarana pemujaan adalah Teras Berundak, Menhir, dan arca. Sementara itu fungsi Batu Kenong sampai sekarang masih diperdebatkan. 
Fungsi teknis sebagai umpak landasan tiang suatu bangunan, tampaknya fungsi Batu Kenong tersebut lebih banyak diyakini oleh para ahli dari pada berfungsi lain, misalnya sebagai media pemujaan.

Selain ditemukan dalam posisi menyebar dan lepas tanpa berkonteks satu sama lain, benda-benda budaya megalitik tersebut juga ditemukan dalam posisi mengelompok dan berkonteks dengan benda sejenis maupun benda megalitik lainnya. Secara umum benda-benda tersebut dan posisinya dapat digambarkan sebagai berikut.

\section{Sarkofagus}

Wadah kubur yang berbentuk seperti Lesung Batu yang bertangkupan (terdiri dari wadah dan tutup) ditemukan di daerah Grujugan, Tlogosari, Tegalampel, Maesan, Klabang, Sukosari, Cerme (Sudarsono, 1995). Sarkofagus ditemukan dalam posisi terpisah (tunggal), mengelompok (berkonteks dengan sarkopagus lain), maupun berkonteks dengan Batu Kenong, Menhir, maupun arca. Sarkofagus yang berkonteks dengan Batu Kenong, Menhir dan Arca Megalitik ditemukan di daerah Grujugan.

\section{Dolmen}

Dolmen sebagai sarana penguburan dan sering disebut sebagai Dolmen Semu (karena tidak berfungsi sebagai sarana pemujaan) ditemukan secara terpisah maupun berkonteks dengan benda megalitik lainnya. Di daerah Grujugan Dolmen ditemukan di lingkungan Sarkofagus. Sementara Dolmen yang ditemukan di daerah Maesan berkonteks dengan Sarkofagus maupun Batu Kenong. Selain di kedua lokasi tersebut, Dolmen juga ditemukan di daerah Pujer, Tlogosari, dan Kecamatan Bondowoso (Sudarsono, 1995).

\section{Kubur Kamar Batu}

Kubur Kamar Batu adalah wadah kubur berbentuk seperti kamar yang dipahat/dibuat pada tebing. Kamar batu íni ditemukan secara terpisah (tunggal) tanpa berkonteks dengan bangunan megalitik lainnya, maupun ditemukan dalam kelompok kecil. Di daerah Tegalampel ditemukan sebuah Kubur Kamar Batu tanpa berkonteks dengan bangunan megalitik, di daerah Tapen ditemukan tiga buah Kubur Kamar Batu yang mengelompok, sedangkan di daerah Kodedek (Kec. Maesan) ditemukan sebuah Kubur 
Kamar Batu yang berdekatan dengan Batu Kenong. Khususnya Kubur Kamar Batu di Kodedek ini agak berbeda dengan Kubur Kamar Batu yang ditemukan di Tegalampel maupun di Tapen. Kubur Kamar Batu di Kodedek tidak dibuat dengan pemahatan pada tebing namun dibuat dengan lempengan-lempengan batu yang disusun dan membentuk kamar di dalam tanah. Selain itu Kubur Kamar Batu juga terdapat di daerah Klabang, Nagasari dan Taal (Sudarsono, 1995).

\section{Teras Berundak}

Sebuah bangunan Teras Berundak yang berfungsi sebagai tempat pemujaan ditemukan di daerah Tlogosari. Pada bangunan ini terdapat fragmen-fragmen bata berukuran besar, 2 lumpang batu, 10 batu tegak dalam posisi berpasangan yang menyerupai nisan, 2 pasang batu tegak sebagai batas jalan (pintu masuk), dan sebuah Umpak Batu tanpa lubang. Selain bangunan Teras Berundak yang berada di pinngir desa dan pada lingkungan sawah ini tidak ada bangunan megalitik lainnya.

\section{Menhir}

Batu tegak yang berfungsi sebagai sarana pemujaan ini ditemukan di daerah Grujugan dan Wringin. Selain itu Menhir juga ditemukan di daerah Tlogosari dan Maesan (Sudarsono, 1995). Di daerah Grujugan, Menhir ditemukan berkonteks dengan Sarkofagus. Sementara di daerah Wringin, sebuah Menhir yang ditemukan tanpa konteks dengan bangunan megalitik lainnya. Menhir ini mempunyai ukuran yang sangat besar dibanding Menhir lainnya yang ditemukan di wilayah Bondowoso.

\section{Arca}

Arca budaya megalitik dan sering disebut sebagai Arca Megalitik ditemukan di daerah Grujugan dan Klabang (Sudarsono, 1995). Seperti telah disebutkan bahwa arca ini berkonteks dengan Sarkofagus.

\section{Batu Kenong}

Batu berbentuk silindris dengan sebuah atau dua buah tonjolan pada bagian ujung atasnya ini banyak ditemukan di daerah Grujugan, Maesan, dan Tlogosari. Selain itu Batu Kenong juga ditemukan di Tamanan dan Pujer (Sudarsono, 1995). Batu Kenong ditemukan secara terpisah ataupun 
berkonteks dengan Sarkofagus maupun Dolmen. Diduga kuat Batu Kenong ini berfungsi sebagai umpak bangunan dari bahan bambu maupun kayu.

Budaya megalitik di wilayah Bondowoso sebagian besar berada (terkosentrasi) di wilayah Grujugan dan Wringin, sehingga pada kedua tempat ini mencerminkan sebagai pusat perkembangan budaya dan pusat permukiman masyarakat megalitik pada masanya. Tinggalan budaya megalitik yang dominan di wilayah Kecamatan Grujugan adalah Batu Kenong, sementara di wilayah Wringin adalah Sarkofagus.

\section{Gambaran Masyarakat Pendukung Budaya Megalitik di Bondowoso}

Masyarakat megalitik merupakan masyarakat yang dalam kehidupannya sarat dengan perilaku yang bersifat magis-religius. Oleh karena itu pada umumnya masyarakat megalitik menghasilkan budaya yang beraneka ragam dan berfungsi berkaitan dengan religi yang dianutnya. Mereka menciptakan bangunan-bangunan dari batu maupun bahan lainnya sebagai sarana pemujaan maupun mengekspresikan keyakinannya.

Masyarakat berbudaya/bertradisi megalitik yang pernah hidup di daerah Bondowoso merupakan masyarakat yang cukup besar. Mereka mendiami wilayah yang luas, tidak hanya di wilayah administratif Bondowoso pada saat ini namun hingga di wilayah sekitarnya seperti Situbondo, Jember, dan Bariyuwangi. Tidak hanya lahan dataran rendah yang mereka manfaatkan, namun mereka juga hidup pada lingkungan lembah-lembah di pegunungan. Oleh karena hidup di pedalaman, diduga kuat mereka mengandalkan pertanian untuk menunjang kehidupan sehari-harinya.

Seperti telah disebutkan bahwa tinggalan megalitik khususnya wadahwadah kubur di Bondowoso beragam. Menarik untuk dikaji terkait dengan latar belakang kemunculan keanekaragaman sarana penguburan ini. Belum dapat diketahui secara pasti faktor yang mepengaruhi munculnya budaya ini, apakah karena faktor perkembangan gaya (trand) atau karena masalah lain seperti strata sosial yang berkembang, misalnya. Apabila munculnya macam-macam bangunan wadah kubur di Bondowoso ini akibat dipengaruhi oleh gaya yang muncul dan berkembang pada masanya maka 
berarti bahwa umur pada masing-masing bentuk wadah kubur tersebut berbeda. Namun sayang sekali kronologi masing-masing wadah kubur tersebut secara pasti belum diketahui. Dan karena itu belum diketahui apakah masing-masing bentuk wadah kubur tersebut muncul/berkembang pada waktu yang berbeda atau pada waktu yang bersamaan.

Masyarakat megalitik di daerah Bondowoso pada masa itu hidup secara mengelompok /memusat pada suatu tempat maupun tersebar di daerahdaerah sampai di lokasi yang cukup terpencil dan jauh dari pusat pemukiman. Sebagai pusat pemukiman adalah daerah Wringin dan Grujugan pada saat ini. Hal ini ditunjukan oleh tinggalan-tinggalan bangunan megalitik yang sangat padat dan terkosentrasi di kedua daerah tersebut. Sementara di luar Wringin dan Grujugan, keberadaan tinggalan bangunan megalitik tidak terkosentrasi dan dengan intensitas sebaran yang tipis. Keadaan sebaran tinggalan bangunan megalitik yang terkosentrasi dan menyebar ini memberikan gambaran pada kita bahwa pada masa itu telah berkembang strata sosial yang cukup kompleks dalam kehidupan mereka, seperti adanya pusat dan daerah/wilayah kekuasaan.

Keberadaan strata sosial pada masyarakat tentunya akan mempengaruhi pada tatanan lain dalam kehidupan bermasyarakat, dan juga akan memepengaruhi budaya yang dihasilkannya. Seperti telah kita bicarakan bahwa ada kemungkinan bahwa munculnya variasi wadah kubur di daerah Bondowoso akibat telah berkembangnya strata sosial pada masyarakat pendukungnya. Jika hal ini benar maka bentuk-bentuk wadah kubur berkaitan dengan golongan-golongan sosial yang ada/terbentuk pada masa itu. Dan ini berarti pula bahwa berbagai bentuk wadah kubur tersebut berkembang pada masa yang sama.

\section{Masa Perkembangan Budaya Megalitik Bondowoso}

Telah disebutkan bahwa tradisi megalitik merupakan salah satu budaya yang dihasilkan manusia yang dipengaruhi/di latar belakangi oleh kepercayaan (religi). Pada hakekatnya kepercayaan yang melatari adalah adanya kekuatan lain di luar kekuatan manusia, adanya kehidupan lanjutan setelah seseorang mati, dan adanya hubungan yang sifatnya pengaruh- 
mempengaruhi antara roh/arwah orang yang telah meninggal dengan orang yang masih hidup. Kepercayaan semacam ini bersifat universal, sehingga hampir pada setiap suku bangsa di dunia berkembang budaya megalitik.

\section{A. Perkembangan Tradisi Megalitik di Indonesia}

Perkembangan budaya megalitik di Indonesia dipengaruhi oleh masuknya budaya tersebut dari luar. Sampai saat ini belum dapat diketahui secara pasti kapan sebenarnya budaya megalitik masuk di wilayah Indonesia. Namun diyakini bahwa masuknya budaya megalitik ke wilayah Indonesia (Nusantara) terjadi dalam dua tahap. Tahap I yang sering disebut sebagai budaya megalitik tua masuk ke Indonesia pada sekitar 4000 tahun yang lalu yaitu bersamaan dengan masuknya teknologi neolitik. Sementara masuknya budaya megaliti tahap II dan sering disebut sebagai budaya megalitik muda terjadi pada sekitar 2300 tahun yang lalu bersamaan dengan masuknya teknologi logam (perunggu-besi) (Geldern, 1945).

Pengaruh tradisi megalitik yang masuk pada tahap I dicirikan oleh hasil budaya bangunan dari batu yang berfungsi sebagai sarana pemujaan. Pada umumnya bangunan megalitik tua di buat tanpa pengerjaan pemahatan, seperti Menhir, Teras Berundak, dan Dolmen. Tradisi megalitik yang masuk pada tahap II dicirikan oleh hasil budaya berupa bangunan dari batu yang berfungsi sebagai sarana penguburan mayat, dan pada umumnya bangunan tersebut dalam pengerjaannya dengan dipahat. Hasil budaya megalitik muda ini di antaranya berupa wadah-wadah kubur seperti Sarkofagus, Peti Kubur Batu, Kamar Kubur Batu, Waruga, dan Kalamba.

Kepercayaan megalitik diperkirakan merupakan kepercayaan keagamaan yang pertama yang dianut oleh masyarakat Nusantara secara luas. Kepercayaan yang bersifat gaib dengan meyakini adanya kekuatan di luar kekuatan manusia ini berkembang subur dan mendalam pada masanya. Oleh karena itu kepercayaan dan budaya megalitik tersebut hingga kini masih mengakar dengan kuatnya pada sebagian masyarakat Indonesia. Bahkan dapat dianggap bahwa budaya yang berkembang pada masa perkembangan kepercayaan megalitik merupakan akar budaya bangsa Indonesia. 
Kesuburan dan kedalaman penghayatan kepercayaan megalitik di Nusantara yang luar biasa kuatnya dibuktikan dengan masih lestarinya tradisi yang terkait dengan kepercayaan tersebut dari masa ke masa. Seperti diketahui bahwa setelah kepercayaan megalitik dengan segala budayanya yang terkait masuk ke wilayah Nusantara, masuk pula agamaagama besar dengan budayanya, yaitu Hindu dan Budha, Islam, kemudian Nasrani. Namun kenyataannya agama-agama besar ini tidak dapat menghapus dan menggantikan semua budaya (tradisi) dan kepercayaan megalitik yang telah berkembang pada masyarakat. Pada beberapa kasus malahan terjadi sinkretisme dan akulturasi budaya antara kepercayaan dan budaya megalitik dengan agama dan budayanya yang baru masuk. Masih dapat dilihat bahwa pada beberapa masyarakat Indonesia saat ini yang telah menganut agama tertentu namun masih juga mempercayai dan menjalankan tradisi yang terkait kepercayaan megalitik dalam kehidupannya.

Di beberapa daerah seperti di Nias, Toraja, Sumba, dan Flores kepercayaan megalitik masih hidup dengan subur hingga saat ini. Tradisi-tradisi yang berakar pada kepercayaan tersebut masih sangat kental mewarnai kehidupan masyarakat sehari-harinya. Di Toraja hingga saat ini masih terdapat tradisi ritual tertentu yang menggunakan hewan korban. Dalam upacara minta kesuburan maupun keselamatan (upacara Ma'bua) digunakan hewan korban ayam dan kerbau (Aneka Ragam Khasanah Budaya Nusantara IX: 189-192)). Sementara dalam upacara kematian/ penguburan yang dapat berlangsung berhari-hari digunakan pula hewan korban tertentu seperti kerbau belang, kerbau yang dikebiri, kerbau hitam, dan babi (Aneka Ragam Khasanah Budaya Nusantara II: 77-81).

Tradisi megalitik di daerah Sumba hingga saat ini masih dilestarikan oleh masyarakat penganut aliran penghayatan kepercayaan Marapu. Mereka masih menjalankan ritual yang ditujukan kepada para leluhur mereka. Dalam penguburan masih digunakan Dolmen, dan untuk pemujaan arwah nenek moyang digunakan Menhir (Sukendar, 1987: 1-16: Aneka Ragam Khasanah Budaya Nusantara VI: 95-98). Sementara di daerah Ngada, Flores tradisi megalitik yang diyakininya mempengaruhi terhadap pola perkampungan mereka. Mereka juga masih mendirikan Menhir dari kayu, 
batu tegak untuk menambat hewan korban (kerbau), melakukan musyawarah pada susunan batu, melakukan upacara perdamaian pada Teras Berundak, manggunakan altar batu dalam upacara musim tanam. Selain itu dalam penguburan jenazah juga disertakan benda-benda bekal kubur (Aneka Ragam Khasanah Budaya Nusantara IV: 75-78).

\section{B. Masa Perkembangan Budaya Megalitik di Bondowoso}

Puncak perkembangan tradisi megalitik di Bondowoso ditandai dengan munculnya bangunan-bangunan dari bahan batu. Jenis batuan beku andesit, breksi andesit, maupun batu pasir yang terdapat di lingkungan mereka dimanfaatkan sebagai sarana/media apresiasi religi. Pemahaman religi, penguasaan teknologi, kondisi sosial ekonomi, dan didukung oleh keberadaan sumberdaya alam merupakan faktor yang memungkinkan berkembangnya budaya megalitik di Bondowoso dengan berbagai variasi hasil budayanya.

Masa perkembangan (mulai kapan dan kapan berakhirnya) budaya megalitik di daerah Bondowoso dan sekitarnya belum dapat diketahui secara pasti. Beberapa artefak yang ditemukan pada ekskavasi, tidak dapat memberikan pertanggalannya. Temuan fragmen keramik yang semula diharapkan dapat memberikan gambaran mengenai masa budaya tersebut berlangsung ternyata meragukan. Pada saat ekskavasi di Pakauman yang merupakan salah satu situs megalitik di Bondowoso telah ditemukan beberapa fragmen keramik pada lapisan atas. Namun ternyata keramik tersebut sangat muda dan merupakan keramik Eropa. Diperkirakan keramik ini sampai di situs setelah budaya megalitik di daerah tersebut berakhir.

Dapat diyakini bahwa pada masa Hindu-Budha, budaya megalitik masih berkembang di daerah Bondowoso. Keyakinan ini didasarkan dari hasil penelitian terhadap budaya serupa yang berada di daerah Jember dan Situbondo. Seperti telah disinggung bahwa pada masa itu budaya megalitik yang diperkirakan berpusat di daerah Wringin dan Grujugan tidak hanya berkembang di daerah Bondowoso saja namun juga tersebar di daerah sekitarnya seperti di wilayah administrasi Situbondo dan Jember pada saat ini. 
Hasil analisis pertanggalan karbon yang dilakukan pada peninggalan megalitik di Situs Krajan, Situbondo menunjukkan umur $1250 \pm 240 \mathrm{BP}$ atau sekitar 1000 - 1500 tahun lalu (abad VI-X M). Data lain mengenai pertanggalan di ketahui pula dari inskripsi angka tahun yang terpahatkan pada sebuah Sarkofagus. Inskripsi tersebut menunjukkan angka tahun 1324 çaka (1402 M). Dari kedua data pertanggalan tersebut menunjukkan bahwa pada sekitar abad VI hingga awal abad XV M, budaya megalitik di situs tersebut masih berkembang. Sementara hasil penelitian pertanggalan karbon yang dilakukan di Situs Doplang, Jember menghasilkan angka tahun $580 \pm 100 \mathrm{BP}$, yang berarti bahwa tradisi megalitik masih berlangsung pada sekitar abad XIV-XVI M di daerah Doplang dan sekitarnya (Prasetyo, 1999: 26-27).

Dari pertanggalan yang diperoleh pada situs megalitik di daerah Situbondo dan Jember tersebut, dapat ditarik gambaran masa perkembangan budaya megalitik yang terjadi di Bondowoso. Pada saat budaya Hindu-Budha telah berkembang di daerah Jawa Timur, budaya megalitik tetap hidup subur bahkan hingga pada akhir masa kerajaan Majapahit. Fenomena masih berkembanganya budaya megalitik pada masa Majapahit di Bondowoso dan sekitarnya sangat menarik mengingat daerah tersebut merupakan daerah kekuasaan Kerajaan Majapahit. Seperti diketahui bahwa kerajaan Majapahit merupakan kerajaan yang besar dan perkembangan agama Hindu-Budha sangat kuat.

Masih suburnya tradisi megalitik yang berkembang di daerah Bondowoso menunjukkan bahwa pengaruh agama Hindu-Budha kurang berpengaruh/. berkembang di daerah tersebut. Kenyataan ini seperti ditunjukkan oleh sedikitnya peninggalan hasil budaya yang berlatarkan kedua agama tersebut di daerah itu. Selain itu dapat juga berarti bahwa Kerajaan Majapahit memberikan kebebasan kepada masyarakatnya untuk memeluk dan mengembangkan kepercayaan/agama di luar agama Hindu dan Budha.

Gambaran masih berkembangnya tradisi megalitik di wilayah kekuasaan kerajaan yang telah memeluk agama tertentu sebagai agama resmi raja (kerajaan) juga didapat dari situs Gunung Mas (Bojonegoro) dan Situs Gunung Bang (Gunungkidul). Walaupun secara pasti pertanggalan pada 
kedua situs megalitik dengan tinggalan budayanya berupa peti kubur batu ini belum diketahui, namun perkiraan umur kedua situs ini dapat diketahui dari sebaran fragmen keramik Cina yang didapatkan di luar kubur pada kedua situs tersebut oleh penulis. Dalam ekskavasi di luar kubur di situs Gunung Mas ditemukan beberapa fragmen keramik Cina (Hidayat, dkk., 1990). Hasil analisis menunjukkan bahwa keramik ini dari Dinasti Yuan. Sementara di luar kubur situs Gunung Bang yang telah teraduk pernah ditemuan pula beberapa fragmen keramik Cina dari masa Dinasti Ming. Kedua temuan keramik tersebut dapat menunjukkan bahwa paling tidak pada abad XIII/XIV tradisi megalitik masih berlangsung di daerah Gunung Mas, dan pada abad XV-XVI tradisi megalitik masih berlangsung di daerah Gunung Bang dan sekitarnya. Hal ini berarti bahwa ketika Kerajaan Majapahit telah berdiri tradisi megalitik di daerah Gunung Mas masih berjalan, dan ketika Kerajaan Mataram Islam telah berdiri tradisi megalitik di Gunung Bang dan sekitarnya masih dilestarikan.

Pada saat ini masih sering dijumpai bahwa keberadaan suatu bangunan megalitik masih ada ikatan batin dengan masyarakat sekitarnya. Ikatan ini berupa pelestarian tradisi yang merupakan unsur tradisi megalitik, yaitu masih dijalankannya tradisi ritual tertentu dalam kehidupan sehari-harinya: Keadaan ini pada umumnya terjadi pada masyarakat yang turun temurun tinggal di lingkungan lokasi keberadaan bangunan megalitik. Pada umumnya masyarakat yang masih melestarikan tradisi ini merupakan keturunan dari masyarakat pendukung budaya megalitik terdahulu.

Di daerah Bondowoso, masyarakat yang tinggal di sekitar situs-situs megalitik pada umumnya merupakan masyarakat keturunan suku bangsa Madura. Masyarakat ini sama sekali tidak mengetahui mengenai latar belakang keberadaan tinggalan bangunan megalitik di lingkungan mereka, dan sama sekali tidak ada keterkaitan fisik maupun ikatan batin. Mereka tidak memiliki tradisi yang terkait dengan keberadaan bangunan megalitik di lingkungan mereka. Berdasarkan hal ini maka dapat diperkirakan bahwa masyarakat Madura yang datang dan menetap di daerah/sekitar situs terjadi ketika tradisi megalitik yang pernah hidup dan berkembang di daerah tersebut telah surut, bahkan mungkin telah mati sama sekali. Masyarakat pendukung tradisi megalitik telah meninggalkan tradisinya karena terdesak oleh keyakinan maupun budaya yang baru. 
Di daerah Jawa Timur bagian timur seperti di wilayah Probolinggo, Lumajang, Jember, Bondowoso dan Situbondo, sebagian masyarakatnya merupakan masyarakat keturunan Madura. Belum dapat diyakini secara pasti mulai kapan masyarakat Madura ini mulai datang secara besarbesaran dan menetap di daerah tersebut. Namun dari beberapa informasi didapat gambaran mengenai hal tersebut. Diperkirakan masyarakat Madura mulai berdatangan dan menetap di Jawa Timur pada awal masa Majapahit terkait dengan pemberian hadiah tanah di daerah Lumajang oleh Raja Majapahit I kepada Adipati Madura yaitu Aria Wiraraja. Akan tetapi migrasi masyarakat Madura ke Jawa Timur secara besar-besaran terjadi pada masa pendudukan Belanda. Pada masa pendudukan Belanda, masyarakat Madura sengaja didatangkan ke Jawa Timur oleh VOC setelah peristiwa pembersihan pedagang-pedagang Inggris yang menduduki daerah Blambangan, Lumajang, dan Malang pada tahun 1757. Migrasi secara besar-besaran juga terjadi pada akhir abad XIX (setelah tahun 1870) terkait dengan maraknya perkebunan tebu dan tembakau di Jawa Timur. Pada masa itu banyak tenaga perkebunan yang didatangkan dari daerah Madura (Khusyairi: 112-114). Oleh karena itu dapat diperkirakan bahwa perkembangan budaya megalitik di Bondowoso telah berakhir pada sekitar abad XVIII-XIX M. 


\section{KEPUSTAKAAN}

Aneka Ragam Khasanah Budaya Nusantara II, IV, VI, IX. Jakarta: Departemen Pendidikan dan Kebudayaan.

Geldern, Robert von Heine. 1945. Prehistoric Research in the Netherlands Indies, Science and Scientists in the Netherlands Indies. New York City. HIm: 129-167.

Hidayat, Muhammad, dkk. 1990. Laporan Hasil Penelitian Arkeologi, Ekskavasi di Gunungmas, Bojonegoro, Jawa Timur. Departemen Pendidikan dan Kebudayaan, Yogyakarta: Balai Arkeologi.

Khusyairi, Ahmad. Agama, Orientasi Politik, dan Kepemimpinan Lokal di Antara Orang-orang Madura di Lumajang, dalam de Jong, Huub, ed. Agama, Kebudayaan, dan Ekonomi: Studi-studi Interdisipliner tentang Masyarakat Madura. Hal. 111-133. Jakarta: Rajawali Pers

Prasetyo, B. (1999). Megalitik Di Situbondo Dan Pengaruh Hindu Di Jawa Timur. Berkala Arkeologi, 19(2), 22-29. https://doi.org/10.30883/jba.v19i2.820

Sudarsono, Slamet Prihadi. 1995. Pola Sebaran Situs-situs Megalitik

di Bondowoso, Kajian Spasial Skala Makro. Skripsi.

Yogyakarta: Fakultas Sastra Universitas Gadjah Mada.

Sukendar, Haris. 1983. Nias, Sumber Data Arkeologi yang Kaya akan

Peninggalan Tradisi Megalitik, Kalpataru 8 Hal. 1-30. Jakarta:

Pusat Penelitian Arkeologi Nasional, Departemen P dan K.

Sukendar, H. (1987). Dolmen's Decoration Patterns In Sumba, Indonesia. Berkala Arkeologi, 8(2), 1-16. https://doi.org/10.30883/jba.v8i2.488 